\title{
Cenozoic micropaleontological biostratigraphy of the LASMO/NSR(V)L Cohasset Producer CP1 P-51 well, Scotian Shelf
}

\author{
F.C. Thomas \\ Atlantic Geoscience Centre, Geological Survey of Canada, Bedford Institute of Oceanography, \\ P.O. Box 1006, Dartmouth, Nova Scotia B2Y 4A2, Canada
}

\author{
Date Received January 20, 1994 \\ Date Accepted March 16, 1994
}

\begin{abstract}
Cuttings samples from the Cenozoic section of the well LASMO/NSR(V)L Cohasset Producer CP1 P-51 (Cohasset field, Scotian Shelf) have been analyzed for microfossil content. These closely spaced samples contain assemblages of foraminifera and other microfossils of Paleocene to early Middle Miocene age, based both on diagnostic planktonic foraminifera and some regional benthic markers. A single major break or reduction in deposition has removed or compressed strata of Late Eocene age, suggesting an unconformity or hiatus between Oligocene and upper Middle Eocene strata.

The microfossil assemblages suggest a middle to upper bathyal environment for this site during most of the Paleogene, grading up into neritic conditions in the Oligocene and Miocene. Relatively silty and later sandy deposits at the site may have reduced or diluted microfossil numbers and diversities. An eroding Mesozoic outcrop in the area contributed Late Cretaceous contaminants during the Paleogene.

Des échantillons d'éclats de roche provenant de la portion cénozoïque du puits producteur de Cohasset CP1 P-51 LASMO/NSR(V)L (champ de Cohasset, plate-forme écossaise) ont été analysés pour leur contenu en microfossiles. Ces échantillons peu espacés contiennent des assemblages de foraminiferes et d'autres microfossiles d'âges allant du Paléocène jusqu'au début du Miocène moyen, d'après de foraminifères planctoniques diagnostiques et quelques marqueurs benthiques régionaux. Une seule discontinuité majeure ou ralentissement de déposition a enlevé ou aminci les strates d'âge Éocène tardif, suggérant une discordance ou un hiatus entre les strates oligocènes et du sommet de l'Éocène moyen.

Les assemblages de microfossiles suggèrent des environnements bathyaux moyens à supérieurs pour ce site pendant la plupart du Paléogène, allant graduellement à des conditions néritiques à l'Oligocène et au Miocène. Des dépôts relativement silteux et plus tard sableux à cet endroit ont pu réduire ou diluer le nombre et la diversité des microfossiles. Un affleurement de roches mésozoïques qui s'érodait dans cette région a introduit des contaminants crétacés pendant le Paléogène.
\end{abstract}

[Traduit par la rédaction]

\section{INTRODUCTION}

Since undersea hydrocarbon exploration began off Nova Scotia in 1967, some 140 wells have been drilled on the Scotian Shelf, including a few on Sable Island. Many of these have encountered significant hydrocarbon shows, and two closely situated fields to the west of Sable Island, Cohasset and Panuke, are currently being developed for oil production.

LASMO NSR(V)L Cohasset Producer CP1 P-51 is the first production well to be drilled on the Cohasset field, some $40 \mathrm{~km}$ west of Sable Island (Fig. 1). Table 1 provides location coordinates and technical information on this well.

As part of federal licensing regulations, the Geological Survey of Canada (GSC) has always been provided with a full suite of ditch cuttings samples from the base of the surface casing down to the total depth of each well drilled. Normally these samples would then be combined with adjacent ones to make composite samples representing $10-\mathrm{m}$ sections, and there may be 20 - or 30 -m unsampled intervals between samples.

Naturally such wide sample spacing has somewhat constrained the biostratigraphic detail obtainable from these suites. The lack of fine-scale resolution, combined with the inherent problem in cuttings samples of downhole contamination by younger material into older (cavings), has long been a problem to biostratigraphers working on this material.

By special arrangement with the well operator (LASMO Nova Scotia Limited), a suite of closely spaced cuttings samples from the Cenozoic interval of the Cohasset Producer CP1 well were provided to the Geological Survey of Canada in order to facilitate a fine-scale biostratigraphic survey of this site. These samples each represent 5-m intervals, and are, for the most part, continuous from $170 \mathrm{~m}$ (base of the $610 \mathrm{~mm}$ conductor casing) to $1040 \mathrm{~m}$ (base of the $445 \mathrm{~mm}$ surface casing). It was hoped that such close sample spacing would provide a more refined biostratigraphic resolution for at least this site in order to give insights into regional Cenozoic depositional processes. Accurate information regarding the history of sedimentation during the Cenozoic is important also for numerical modelling studies of the region's pore-pressure history (Mudford and Best, 1989; Williamson, 1992).

\section{Methods}

Each sample was oven-dried, then weighed. Weights ranged from 100 to over $600 \mathrm{~g}$, but most were between 200 and $400 \mathrm{~g}$. No presoaking in any detergent or other chemical was required, 


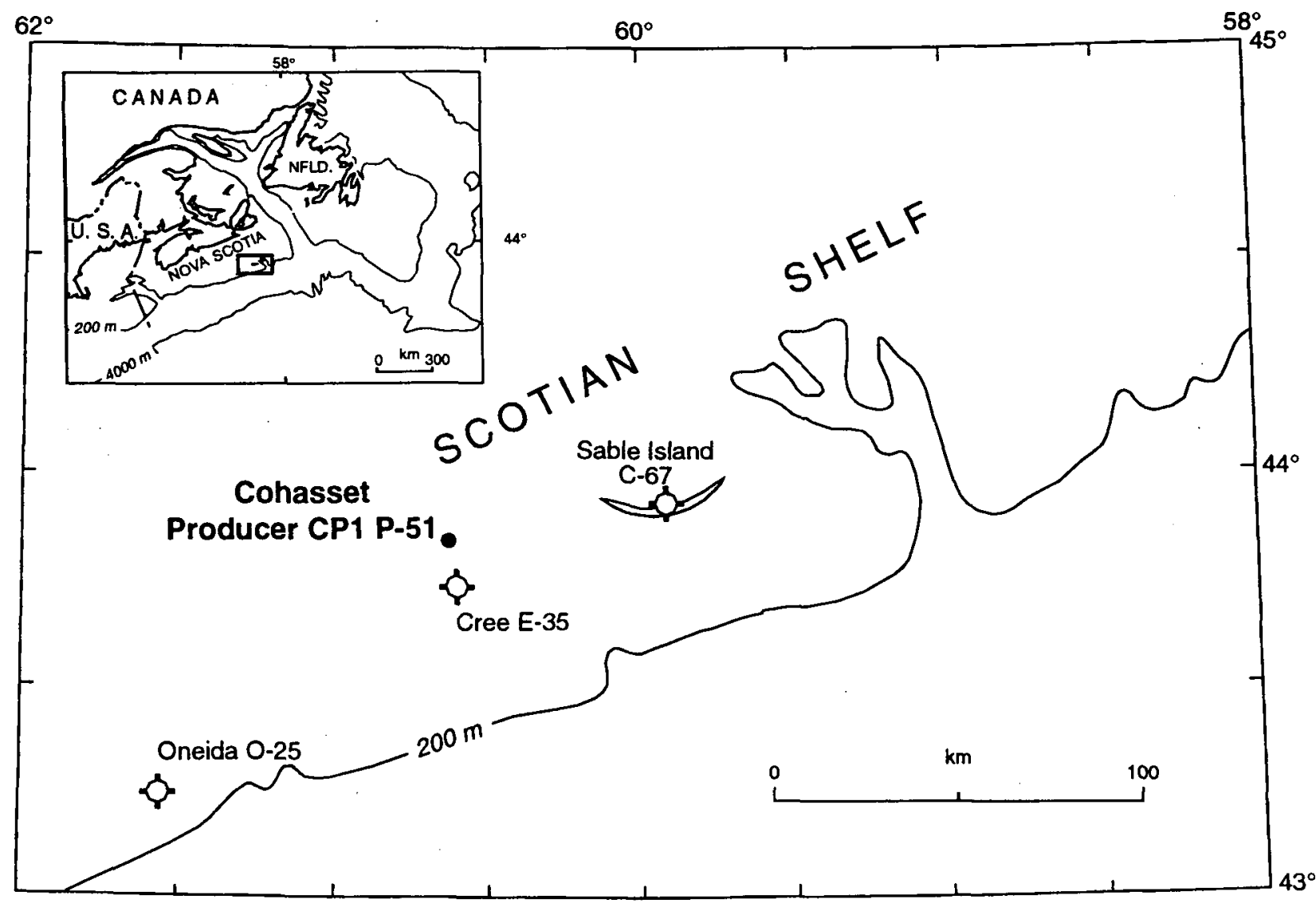

Fig. 1. Map showing locations of LASMO/NSR(V)L Cohasset Producer CP1 P-51, Cree E-35, Oneida O-25 and Sable Island C-67 wells.

as all the samples were unconsolidated. The samples were washed through a stack of sieves, the top sieve with a 1.700 $\mathrm{mm}$ opening, the middle sieve with a $0.250 \mathrm{~mm}$ opening and a bottom sieve with a $0.063 \mathrm{~mm}$ opening. The residue was later dried and weighed, and a 5 to $60 \mathrm{~g}$ subsample of the 0.250 to $1.700 \mathrm{~mm}$ size fraction was set aside for palynological analysis.

The samples were then dry-seived, and a small portion of the $>0.150 \mathrm{~mm}$ cut was examined and hand-picked for microfossil content. The resulting microfossil assemblages were then placed in separate 60-grid slides and analysed. A few samples yielded molluscs or other non-protozoan taxa which were too large to fit into the slides; these were placed separately in small vials.

In determining the stratigraphic breakdown of this or any other well entirely from cuttings, only the uppermost occurrence (the so-called stratigraphic exit) of a given marker species can have significant stratigraphic value; its earliest or lowest occurrence (the stratigraphic entrance) may be artificially lowered by downhole caving.

\section{Results}

Relatively large amounts of silt and sand were present in most samples, with the typical clay content exceeding $50 \%$ only in the lowermost $100 \mathrm{~m}$ or so. Above that, washing usually only reduced the dry weights by 10 to $35 \%$. The upper $200 \mathrm{~m}$ contained large amounts of sand-sized clastics, whereas farther down the sands tended to be replaced by silts. Appendix A lists all samples together with the percentage of sediment grains $>63$ microns in size in each, and Figure 2 graphically represents this information.

Microfossil suites commonly contained foraminiferal tests, both planktonic and benthic, and mollusc fragments or, more rarely, entire shells. Also present in some levels were ostracodes, small fish teeth or otoliths and occasional echinoderm spines or plates.

As to be expected in sediments with such large amounts of coarse clastics, the samples generally did not yield very rich or diverse assemblages, and many of the biostratigraphic marker species commonly used in Canadian Atlantic Margin wells were absent or very rare. Also, the sandy and unconsolidated nature of the section resulted in large-scale caving of overlying material into lower levels, with the result that microfossil assemblages in many levels contain amounts of demonstrably younger taxa as contaminants.

In spite of these problems, enough useful taxa were found to construct a basic biostratigraphic framework for the sampled Cenozoic portion of this site (Fig. 2). The downhole succession of microfossil taxa is provided as Appendix B.

This age-depth information can be viewed graphically as a sedimentation rate curve for the Cenozoic wedge at this location. Figure 3 shows relatively high rates of sedimentation during the Early and Middle Eocene with an unconformity apparent in early Late Eocene. During the Oligocene rates were relatively low, but increased during the Early Miocene and then declined during the Middle Miocene to present day rates. 
Table 1. Technical data on LASMO/NSR(V)L Cohasset Producer CP1 P-51.

GSC Locality No.

Location:

Water Depth:

Total Depth Drilled:

Rotary Table Height Above Sea Level: Rotary Table Height Above Sea Floor: Interval Studied:

Data Release Date:
D-328

$43^{\circ} 50^{\prime} 57.180^{\prime \prime} \mathrm{N} ; 60^{\circ} 37^{\prime} 39.972^{\prime \prime} \mathrm{W}$

$43 \mathrm{~m}$

$2472.0 \mathrm{~m}$ (measured depth, $2330.6 \mathrm{~m}$

true vertical depth; directionally

drilled from base of $340 \mathrm{~mm}$ casing

at $1040 \mathrm{~m}$ to T.D.)

$41.5 \mathrm{~m}$

$84.5 \mathrm{~m}$

$170-1010 \mathrm{~m}$

August 5, 1993

\section{COMMENTS ON THE BIOSTRATIGRAPHIC SUCCESSION}

The Cenozoic section of the Cohasset CP1 well runs from the top of the sampled interval at $170 \mathrm{~m}$ down to $1010 \mathrm{~m}$ where the microfossil assemblage is almost entirely Late Cretaceous in age. The benthic markers commonly used to subdivide the Tertiary of the East Coast (Gradstein and Agterberg, 1982) are not all present at this site, particularly some of the nominate forms. This deficiency places more reliance on the small numbers of planktonic foraminifera present and on some of the other benthic forms widespread in the region.

Paleoecological interpretations are based largely on the ratios of planktonic to benthic specimens and the nature of the benthic species present. Also considered are relative numbers of non-Protozoan taxa such as molluscs and echinoderms.

The microfossil assemblage in a slide made from any cuttings sample from any site may contain as many as four distinct components. These are: (1) the preserved in situ population of taxa from that level; (2) coeval taxa which have been transported into the site from some nearby but possibly distinct environment; (3) specimens from overlying, younger material that has caved downwards; and (4) older, allochthonous material that was transported to the site during original deposition. In the case of this reworked material, if it consists of species that were extinct at the time of deposition, this allochthonous fraction can be easily recognized and disregarded. The same can be said for caved material representing taxa which are too young.

One difficulty in some East Coast wells, including this one, lies in the possible caving of certain long-ranging species from the neritic-facies Neogene section into the deeper Paleogene samples, confusing the paleoecological interpretation. This means that even greater circumspection must be employed in attaching paleoecological meanings to these fossil assemblages.

Having stated that, it is known that, barring subsidence, the normal course of sedimentation in any basin is for it to gradually infill and become more shallow through time. Therefore, one would expect fossil assemblages to reflect this changing bathymetry down through the section. Often, however, subsidence occurs because of this increasing weight of sedimentary infill and may more or less balance the sedimentary input, in effect allowing the basin to remain "deep" even as the basin floor is built up. Hence, if some shallow-facies indicators per- sist down through a section which becomes more and more dominated by deeper water taxa, they can usually be assumed to represent contamination from the drilling process, or perhaps material transported downslope at the time of deposition. In the case of caving, their common co-occurrence with anomalously young taxa often facilitate recognition.

\section{CENOZOIC BIOSTRATIGRAPHIC SUCCESSION}

The following is a brief description of the microfossil suites encountered in the various Cenozoic levels of the Cohasset CP1 well.

The top sample $(170 \mathrm{~m})$ contains a small number of shallow-water benthics dominated by Elphidium clavatum gr. These are typical representatives of Plio-Pleistocene levels in other wells, and are commonly encountered in the topmost sample of East Coast sites. However, because of the engineering processes involved at the top of the surface casing from where this sample comes, it may well be composed entirely of caved material from above.

Below this, the sample from $175 \mathrm{~m}$ appears to contain an older assemblage, still reflecting neritic conditions but containing a few planktonic species including Globorotalia fohsi peripheroronda and Globigerina bulloides. The co-occurrence of these two taxa denote an early Middle Miocene age for this level (N9 or N10 in the scheme devised by Blow [1969]). The benthic suite is composed partly of taxa still extant and found in middle to deep neritic environments, and partly of some neritic forms as above, probably caved. All taxa are calcareous and preservation is generally good.

From 180 to $235 \mathrm{~m}$ sporadic occurrences of such diagnostic planktonics as Globigerina aff. angustiumbilicata, $G$. praebulloides, Globoquadrina praedehiscens and Globorotalia praescitula indicate an Early Miocene age (Bolli and Saunders, 1985). A wide assortment of benthic foraminifera are present, with Lenticulinids perhaps the single most common group. Also present in many samples are Bolivina cf. dilatata, Caucasina elongata, Florilus pizzarense and Parafrondicularia spp. Echinoid spines and mollusc fragments are also common constituents. Virtually all benthic foraminifera are calcareous, and in a reasonably good state of preservation.

The interval 240 to $340 \mathrm{~m}$ is of uncertain age, containing 


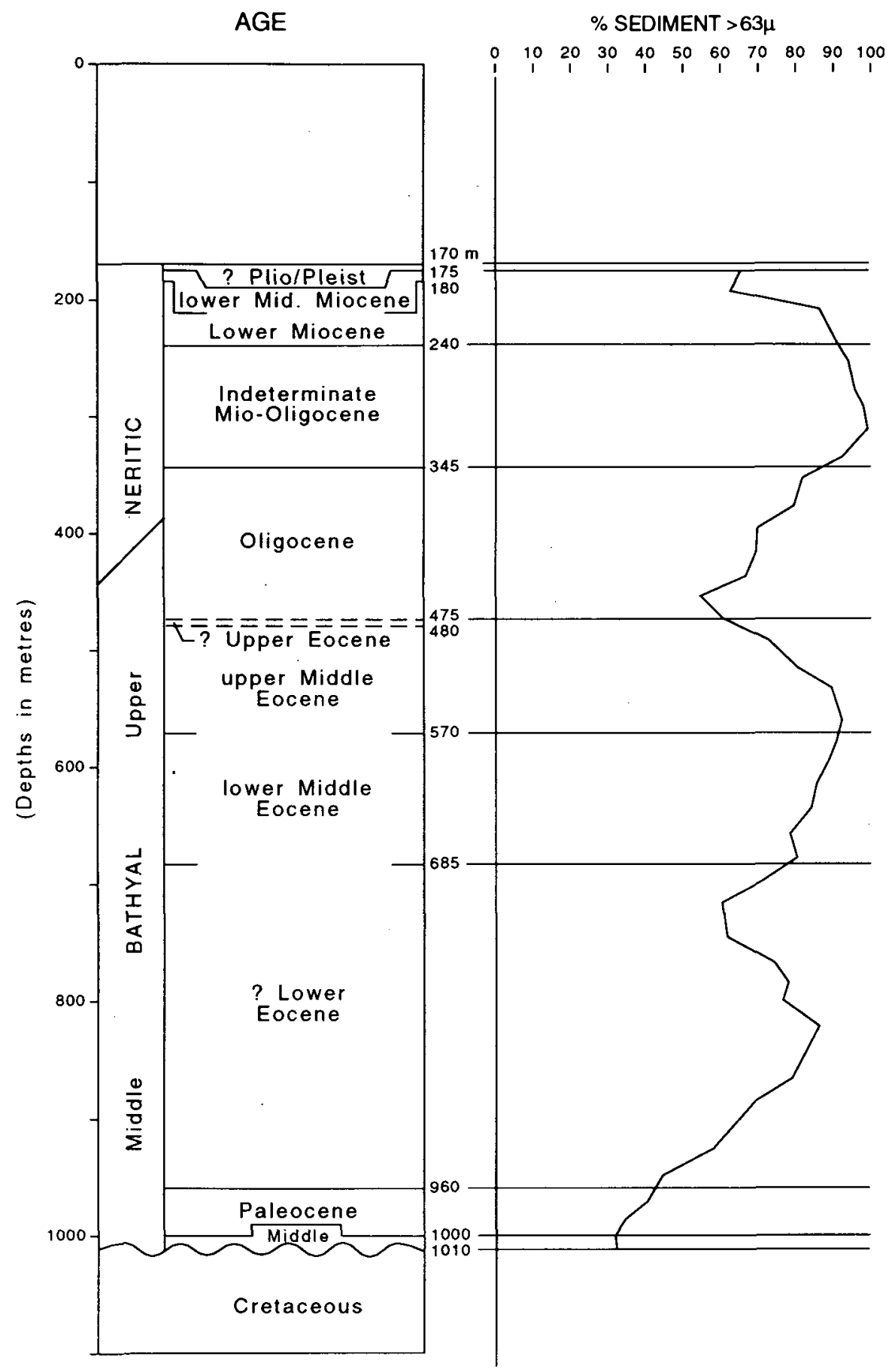

Fig. 2. Biostratigraphic column and paleoenvironments of the Cenozoic section of Cohasset Producer CP1 P-51 well. Depth in metres below Rotary Table. At right are the percentages of sediment $>63 \mu$ in size, averaged over $20 \mathrm{~m}$ intervals.

in its planktonic component certain forms such as Globoquadrina aff. venezuelana and Globorotalia continuosa which may span the Oligocene-Miocene boundary (which very likely lies somewhere in this section). The benthic foraminiferal fauna is less diverse than above, though mollusc fragments remain common. Water depth at the site was probably still in the neritic range.

A few good Oligocene planktonic indicators (e.g., Globorotalia opima nana) appear in the interval 345 to $470 \mathrm{~m}$, and the benthic fauna is somewhat richer and more diverse than the overlying unit. Uvigerinids are common, as are Lenticulinids, though any number of these latter may be caved from above. Small numbers of some other forms such as Hoeglundina elegans, Plectofrondicularia vaughani and Cibicidoides laurisae suggest a somewhat deeper environment (outer neritic to upper bathyal) for the Oligocene series. At $460 \mathrm{~m}$ there is an unusually large number of very small foraminifera, including the planktonic form Cassigerinella chipolensis, and several small benthics of uncertain affinities. Also present in the lower parts of this section are small numbers of reworked Late Cretaceous planktonics. Another spurious find is a single specimen of Globorotalia menardi " $\mathrm{A}$ ", a Middle Miocene to Recent taxon 


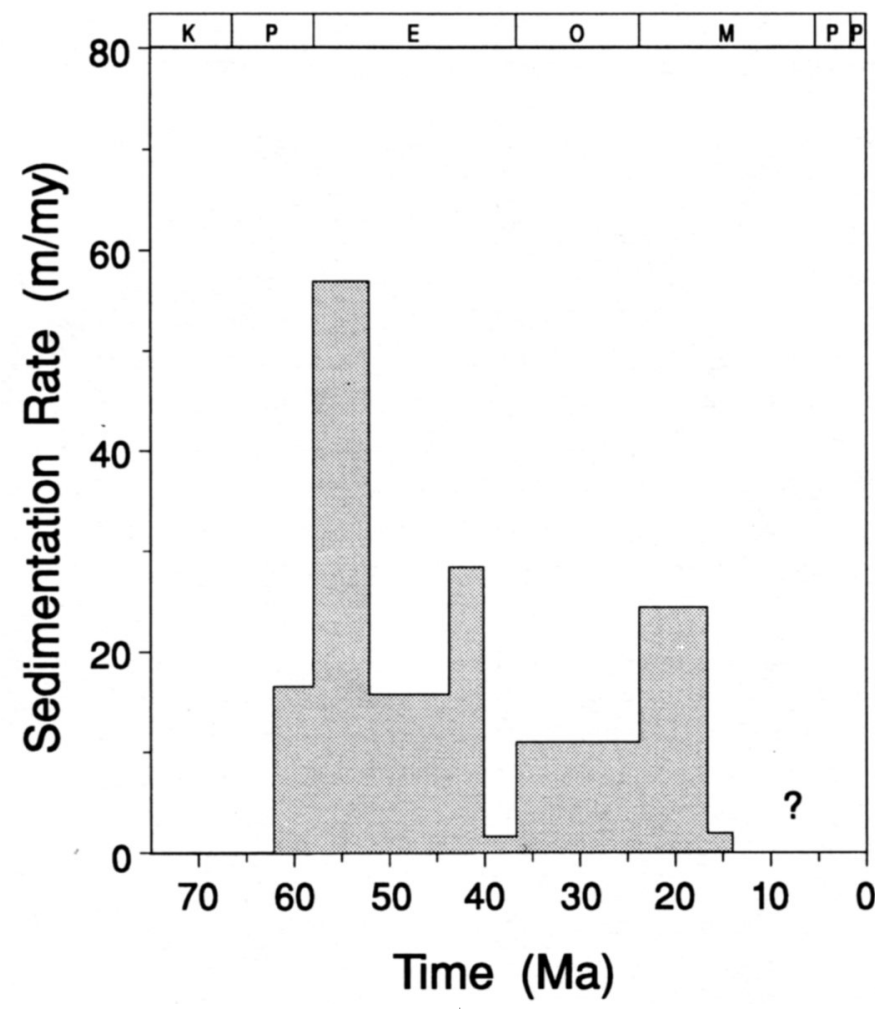

Fig. 3. Cenozoic sedimentation rates of LASMO/NSR(V)L Cohasset Producer CP1 P-51 well.

obviously caved from higher levels, yet not encountered in the Miocene section. Its large size, good preservation and unique appearance preclude the possibility of misidentification. Agglutinated taxa are still very rare. The large amounts of relatively coarse sand-sized clastics in these upper levels of the well suggest a hydrodynamically active environment.

The sample from $470 \mathrm{~m}$ was very rich in glauconite grains (approximately $40 \%$ of the fraction $>0.063 \mathrm{~mm}$ ). This high content continued down to the $490 \mathrm{~m}$ level, although some or all of this lower material may have been caved. This mineralization may indicate a cessation or reduced rate of sedimentation. At $475 \mathrm{~m}$ a single specimen of Globigerinatheka cf. index suggests a late Middle to Late Eocene age for this level, but the few other planktonics present are typically Oligocene, perhaps caved. Evidence for a possible unconformity just above the $\mathbf{4 7 0}$ $\mathrm{m}$ level also comes from the CPI sonic log, which shows a velocity shift to higher values at this point (J. Wade, personal communication, 1993).

From these observations it appears possible that the entire Upper Eocene in this well is missing or at least very compressed. At $\mathbf{4 8 0} \mathrm{m}$, several clearly late Middle Eocene planktonic forms appear (Acarinina spinuloinflata, Truncorotalites rohri and Turborotalia pomeroli), together with a few Paleogene benthics. From this point down to $565 \mathrm{~m}$, assemblages are typically fairly poor, although preservation of most specimens remains good. A slight increase in relative numbers of planktonics to benthics and agglutinated to calcareous benthics both attest to deeper, probably upper bathyal depositional conditions.

The sample from $570 \mathrm{~m}$ contains a few specimens of Acarinina densa, a common lower Middle Eocene marker in
East Coast wells (Gradstein and Agterberg, 1982). Otherwise, microfossil assemblages remain impoverished through the next $100 \mathrm{~m}$, although there are slight increases in the numbers of reworked Late Cretaceous taxa, suggesting a nearby erosional source, presumably upslope from the Cohasset site. A few specimens of Limacina canadensis, a pteropod usually found as pyritized internal casts in many East Coast sites, are found in this interval, although here they remain in their original calcareous form. Upper bathyal depositional conditions are indicated for this interval.

At $685 \mathrm{~m}$ two specimens of Pseudohastigerina wilcoxensis suggest a Lower Eocene level; this planktonic form is a common constituent of Early Eocene assemblages in other wells of the Scotian Shelf and Slope (Gradstein and Agterberg, 1982). This section continues down to $955 \mathrm{~m}$, with fairly poor assemblages containing small numbers of planktonic and benthic foraminifera together with some mollusc fragments, fish remains and ostracodes. Some benthic forms include common Loxostoma gemmum, Lenticulina cf. whitei and several Buliminids. Agglutinated taxa remain very rare, and Late Cretaceous planktonic taxa continue to appear regularly.

The sample from $960 \mathrm{~m}$ contains a single damaged specimen closely resembling the benthic Nuttalinella florealis, and just below this several samples contain Pyramidita rudita and one or two other typically bathyal benthics suggesting a Paleocene age (Tjalsma and Lohmann, 1983). At $990 \mathrm{~m}$ the planktonic Paleocene marker Planorotalites chapmani occurs, and at $1000 \mathrm{~m}$ two specimens of an intermediate Planorotalites chapmani-compressa form suggest a probable Middle Paleocene (p. 3 of Blow, 1969) age for this level. A middle to upper bathyal depth is suggested by the microfossils in this section.

There is no sample from $1005 \mathrm{~m}$, but at $1010 \mathrm{~m}$ the sample contains a Santonian assemblage with common Gavelinellids, Globotruncanids and Globorotalites multiseptus and only a minor caved Tertiary component (P. Ascoli, personal communication, 1993).

\section{Discussion}

The biostratigraphic succession of Cenozoic assemblages is in itself not remarkable, merely reflecting the gradual shoaling of the site from a middle to upper bathyal environment at the start of the Tertiary to a neritic one at the top of the truncated Miocene interval. Certain aspects of this section are, however, of some interest because of their implications for the Cenozoic history of the site.

The unconformity underlying the Paleocene encompasses Maastrichtian and Campanian deposition, and may also include the Lower Paleocene. Beneath it is the Wyandot Formation, a chalky unit of Santonian to, where complete, Maastrichtian age (Doeven, 1983), locally important as a seismic marker (Wade and MacLean, 1990). Furthermore, local seismic evidence suggests a hiatus at the Cretaceous/Tertiary boundary and indicates some erosion of the uppermost Cretaceous, probably during the Early Paleocene (J.A. Wade, personal communication, 1993).

The apparent Late Eocene unconformity or greatly reduced rate of sedimentation may correlate to similar gaps in some other previously studied Scotian Shelf wells in this area such as Oneida 
O-25 and Sable Island C-67 (Ascoli, 1976) and Cree E-35 (F.C. Thomas, unpublished data, 1992).

The large amount of glauconite in the samples at $\mathbf{4 7 0}$ to $470 \mathrm{~m}$ may be related to similar events in the Oneida $0-25$, Sable Island C-67 and Cree E-35 wells. These sites also contain samples in Late Eocene or younger levels very rich in this mineral, so episodes of greatly reduced or non-deposition may have occurred repeatedly in the area through the later Tertiary.

Pyritized diatoms are completely absent from the Cenozoic section of Cohasset Producer 1 P-51, presumably because of its comparatively shallow depositional environments in the Neogene at least. Certain other wells on the Scotian Shelf from deeper areas contain small numbers of these taxa in at least some Cenozoic levels (Thomas and Gradstein, 1981; F.C. Thomas, unpublished data, 1994).

Similarly, certain benthic species commonly used (and often present in large numbers) in the quantitative zonation scheme of Gradstein and Agterberg (1982) for the northwestern Atlantic margin are completely absent, such as the Lower Eocene marker Spiroplectammina spectabilis. Others, such as the Lower Miocene Spiroplectammina carinata and the Eocene pteropod Limacina canadensis are very rare. Presumably some environmental factor(s) caused these anomalies; possibilities include the relatively coarse (i.e., sandy and silty) nature of the sediments and the relatively shallow water.

This latter factor may be the reason for the good preservational state and complete absence of pyritized casts of foraminifera in the Cenozoic of this well.

The reworked Late Cretaceous foraminifera appearing in this site from upper Middle Eocene levels down strongly indicate an eroding Mesozoic source somewhere in the vicinity. Furthermore, the good state of preservation of even the larger Globotruncanids suggest a close proximity for this supply, yet the nearest obvious source of such material is the erosional subcrop of the Wyandot seismic marker, some $70 \mathrm{~km}$ or more to the northwest (Wade and MacLean, 1990, fig. 5.44).

The position of the Quaternary/Tertiary boundary somewhere higher than $175 \mathrm{~m}$ below RT (= $134 \mathrm{~m}$ below sea level) is somewhat higher than the $220 \mathrm{~m}$ b.s.l. reported by Boyd et al. (1988) in a borehole on Sable Island, some $40 \mathrm{~km}$ to the east.

\section{Conclusions}

Micropaleontological analysis of the Cohasset Producer CP1 P-51 well suggests the following depositional/environmental history for the site: (1) More or less continuous deposition in a middle to upper bathyal setting occurred through the Middle Paleocene and Early and Middle Eocene. A predominantly calcareous benthic foraminiferal fauna with small numbers of planktonics colonized the site, its numbers perhaps constrained by the silty substrate, especially above the Paleocene. (2) Common Late Cretaceous contamination in the these levels indicate contribution from an unknown eroding Mesozoic source. (3) During the Late Eocene, there was either no deposition at the site, or very reduced sedimentation. Abundant glauconite suggests an extended period of subaqueous exposure at no greater than upper bathyal depth. (4) Oligocene and Miocene faunas reflect the continual shallowing of the site as sediments accu- mulate. Coarser clastic materials in this and higher intervals attest to a more dynamic sedimentological regime.

\section{ACKNOWLEDGEMENTS}

Many thanks to J.A. Wade and M.A. Williamson (AGC) for critical review of the early stages of this manuscript and to D.E. Brown of the Canada-Nova Scotia Offshore Petroleum Board and D.B. Scott of Dalhousie University whose reviews for the journal greatly improved the final manuscript. Thanks also to P. Ascoli (AGC) for helpful comments, N. Koziel (AGC) for word processing, G.M. Grant (AGC) for figure preparation, and S. King (AGC) for technical assistance. This is Geological Survey of Canada Contribution No. 45793.

Ascol, P. 1976. Foraminiferal and ostracod biostratigraphy of the Mesozoic-Cenozoic, Scotian Shelf, Atlantic Canada. In Proceedings of the 1st International Symposium on Benthonic Foraminifera of Continental Margins, Part B, Paleoecology and Biostratigraphy. Maritime Sediments, Special Publication 1, pp. 653-771.

BLow, W.H. 1969. Late Middle Eocene to Recent planktonic foraminiferal biostratigraphy. Proceedings of the First International Conference on Planktonic Microfossils, Geneva, 1967, 1, pp. 199. 422.

Bolli, H.M. and SAunders, J.B. 1985. Oligocene to Holocene low latitude planktic foraminifera. In Plankton Stratigraphy. Edited by H.M. Bolli, J.B. Saunders and K. Perch-Nielsen. Cambridge University Press, Cambridge, United Kingdom, pp. 155-262.

Boyd, R., Scott, D.B., and Douma, M. 1988. Glacial tunnel valleys and Quaternary history of the outer Scotian Shelf. Nature, 333, pp. 61-64.

Doeven, P.H. 1983. Cretaceous nannofossil stratigraphy and paleoecology of the Canadian Atlantic Margin. Geological Survey of Canada, Bulletin 356, 70 p.

Gradstein, F.M. and Agterberg, F.P. 1982. Models of Cenozoic foraminiferal stratigraphy - Northwestern Atlantic Margin. In Quantitative Stratigraphic Correlation. Edited by J.M. Cubitt and R.A. Reyment. John Wiley and Sons Limited, Chichester, United Kingdom, pp. 119-174.

MudForD, B.S. and BeSt, M.E. 1989. Venture gas field, offshore Nova Scotia: case study of overpressuring in region of low sedimentation rates. American Association of Petroleum Geologists Bulletin, 73, pp. 1383-1396

Thomas, F.C. and Gradstern, F.M. 1981. Tertiary subsurface correlations using pyritized diatoms, offshore eastern Canada. In Current Research, Part B, Geological Survey of Canada, Paper 811B, pp. 17-23

TJalsma, R.C. and LohmanN, G.P. 1983. Paleocene-Eocene bathyal and abyssal benthic foraminifera from the Atlantic Ocean. Micropaleontology, Special Publication 4, 90 p.

WADE, J.A. and MACLEAN, B.C. 1990. The geology of the southeastern margin of Canada, Chapter 5. In Geology of the Continental Margin of Eastern Canada. Edited by M.J. Keen and G.L. Williams. Geological Survey of Canada, Geology of Canada, 2, pp. 167. 238.

Williamson, M.A. 1992. The subsidence, compaction, thermal and maturation history of the Egret Member source rock, Jeanne d'Arc Basin, offshore Newfoundland. Bulletin of Canadian Petroleum Geology, 40(2), pp. 136-150. 
Appendix A. List of sample depths (metres below Rotary Table) and percentages of dry weight $>63$ microns.

\begin{tabular}{|c|c|c|c|c|c|c|c|}
\hline (m) & $\%>0.063 \mathrm{~mm}$ & $(\mathrm{~m})$ & $\%>0.063 \mathrm{~mm}$ & $(\mathrm{~m})$ & $\%>0.063 \mathrm{~mm}$ & (m) & $\%>0.063 \mathrm{~mm}$ \\
\hline 170 & 75.6 & 390 & 72.8 & 610 & 85.4 & 840 & 87.4 \\
\hline 175 & 49.3 & 395 & 72.3 & 615 & 77.8 & 845 & 86.0 \\
\hline 180 & 59.1 & 400 & 66.9 & 620 & 88.9 & 850 & 79.5 \\
\hline 185 & 77.1 & 405 & 70.1 & 625 & 90.3 & 855 & 78.0 \\
\hline 190 & 68.9 & 410 & 68.0 & 630 & 82.9 & 860 & 79.8 \\
\hline 195 & 56.0 & 415 & 67.9 & 635 & 80.3 & 865 & 80.1 \\
\hline 200 & 59.4 & 420 & 72.8 & 640 & 84.4 & 870 & 74.3 \\
\hline 205 & 68.3 & 425 & 68.4 & 650 & 88.3 & 875 & -- \\
\hline 210 & 82.8 & 430 & 63.6 & 655 & 77.1 & 880 & -- \\
\hline 215 & 88.2 & 435 & 72.1 & 660 & 79.2 & 885 & 71.4 \\
\hline 220 & 84.9 & 440 & 66.3 & 665 & 76.3 & 890 & 69.1 \\
\hline 225 & 91.6 & 445 & 65.0 & 670 & 81.2 & 895 & 67.3 \\
\hline 230 & 88.5 & 450 & 60.0 & 675 & 78.5 & 900 & 59.8 \\
\hline 235 & 91.8 & 455 & 54.7 & 680 & 79.4 & 905 & 64.4 \\
\hline 240 & 92.7 & 460 & 50.0 & 685 & 80.8 & 910 & 68.5 \\
\hline 245 & 88.4 & 465 & 51.2 & 690 & 82.0 & 915 & 59.6 \\
\hline 250 & 91.9 & 470 & 57.3 & 695 & 82.8 & 920 & 62.1 \\
\hline 255 & 91.0 & 475 & 64.9 & 700 & 65.5 & 925 & 56.4 \\
\hline 260 & 94.7 & 480 & 65.3 & 705 & 67.0 & 930 & 53.4 \\
\hline 265 & 95.4 & 485 & 58.6 & 710 & 68.7 & 935 & 55.2 \\
\hline 270 & 95.7 & 490 & 55.7 & 715 & 65.8 & 940 & 49.0 \\
\hline 275 & 94.8 & 495 & 75.1 & 720 & 55.8 & 945 & 49.4 \\
\hline 280 & 96.8 & 500 & 78.2 & 725 & 56.9 & 950 & 39.8 \\
\hline 285 & 91.8 & 505 & 80.4 & 730 & 61.5 & 955 & 43.2 \\
\hline 290 & 97.4 & 510 & 83.6 & 735 & 60.1 & 960 & 42.5 \\
\hline 295 & 97.3 & 515 & 76.3 & 740 & 65.9 & 965 & 43.1 \\
\hline 300 & 97.3 & 520 & 80.7 & 745 & 54.7 & 970 & 36.2 \\
\hline 305 & 97.2 & 525 & 82.8 & 755 & 68.9 & 975 & 38.6 \\
\hline 310 & 97.6 & 530 & 88.2 & 760 & 73.3 & 980 & 39.4 \\
\hline 315 & 99.1 & 535 & 87.3 & 765 & 73.6 & 985 & 35.1 \\
\hline 320 & 97.3 & 540 & 89.7 & 770 & 74.0 & 990 & 32.4 \\
\hline 325 & 99.5 & 545 & 90.1 & 775 & 72.7 & 995 & 29.4 \\
\hline 330 & 95.7 & 550 & 91.5 & 780 & 64.6 & 1000 & 29.7 \\
\hline 335 & 96.2 & 555 & 92.3 & 785 & 83.2 & 1010 & 32.7 \\
\hline 340 & 90.5 & 560 & 92.5 & 790 & 83.0 & & \\
\hline 345 & 88.4 & 565 & 92.2 & 795 & 81.2 & & \\
\hline 350 & 83.5 & 570 & 90.9 & 800 & 77.4 & & \\
\hline 355 & 85.0 & 575 & 90.9 & 805 & 72.7 & & \\
\hline 360 & -- & 580 & 91.4 & 810 & 78.6 & & \\
\hline 365 & 79.0 & 585 & 90.6 & 815 & 78.3 & & \\
\hline 370 & 77.0 & 590 & 87.7 & 820 & 85.0 & & \\
\hline 375 & 81.4 & 595 & 89.5 & 825 & 88.1 & & \\
\hline 380 & 81.5 & 600 & 89.4 & 830 & 86.4 & & \\
\hline 385 & 78.5 & 605 & 85.8 & 835 & 86.5 & & \\
\hline
\end{tabular}


Appendix B. Stratigraphic succession of Cenozoic microfossil tops in LASMO/NSR(V)L Cohasset Producer CP1 P-51. Depths in metres.

Plio-Pleistocene (??)

170 Dentalina cf. baggi Galloway and Wissler Elphidium clavatum gr. Cushman

Lenticulina sp.

Nonion labradoricum (Dawson)

Pyrgo sp.

Quinqueloculina sp.

lower Middle Miocene

175 Bolivina sp.

Buccella frigida (Cushman)

Caucasina elongata (d'Orbigny)

Cibicides lobatulus (Walker and Jacob)

Globigerina bulloides d'Orbigny

Globigerina sp.

Globorotalia fohsi peripheroronda Blow and Banner

Globorotalia inflata (d'Orbigny)

Quinqueloculina seminulum (Linné)

Uvigerina peregrina Cushman

Lower Miocene

180

Bolivina dilatata (Reuss)

Bulimina sp.12

Globigerina aff. angustiumbilicata Bolli

Globigerina praebulloides Blow

Globocassidulina subglobosa (Brady)

Globorotalia praescitula Blow

Lenticulina alatolimbata (Gumbel)

Lenticulina calcar (Linné)

Melonis pompiliodes (Fichtel and Moll)

Rectuvigerina transversa (Cushman)

Sphaeroidina bulloides d'Orbigny

Stilostomella sp.

185 Cibicidoides ?pachyderma (Rzehak)

Lenticulina cf. articulata (Reuss)

Nodosaria sp.

Sigmomorphina aff. vaughanii Cushman and Ozawa

190 Hanzawai sp.

Uvigerina canariensis d'Orbigny

195 Buliminella elegantissima (d'Orbigny)

Florilus pizzarensis (Berry)

Globoquadrina praedehiscens Blow and Banner

Scaphopod sp.1

200 Cibicidoides sp.

Globoquadrina dehiscens (Chapman, Parr and Collins)

Guttulina sp.

Parafrondicularia miocenica (Cushman)

Parafrondicularia sp.

205 Globigerinoides trilobus (Reuss)

Globobulimina sp.

Lagena sp.

Planulina cf. dohertyi (Galloway and Morrey)

Spiroloculina canaliculata d'Orbigny
210 Guttulina problema d'Orbigny

Karreriella cf. chapapotensis (Cole)

Pseudopolymorphina? sp.

Rosalina sp.

$220 \quad$ Nodosaria sp.4

Nonionella sp.

225 Gyroidina sp.

Lenticulina spp.

230 Scaphopod sp.

Indeterminate Mio-Oligocene

240 Bathysiphon sp.

Globoquadrina cf. venezuelana (Hedberg)

255 Megaspore sp.

260 Ceratobulimina cf. contraria (Reuss)

335 Marginulina aff. bachei Bailey

Melonis cf. sphaeroides Voloshinova

Uvigerina ex. gr. miozea-nuttali Thomas

340 Eponides umbonatus (Reuss)

Frondicularia? sp.

Fursenkoina? sp.

Globigerina sp.

Globorotalia continuosa Blow

Globorotalia obesa Bolli

Lenticulina iota (Cushman)

Nodosaria sp. 1

Nodosaria sp. 19

Siphonina tenuicarinata Cushman

Spiroplectammina carinata (d'Orbigny)

Oligocene

345 Globorotalia opima/nana/continuosa gr. Bolli

350 Gyroidina girardana (Reuss)

Lenticulina aff. totomiensis Makiyama

Pseudoglandulina humilis (Roemer)

360 Gyroidina soldanii d'Orbigny

Hoeglundina elegans (d'Orbigny)

Karreriella sp.

Melonis barleeanum (Williamson)

Nodosaria sp.1

Robertina? sp.

365

370

375

380

385

390

395

410

415

420

Globorotalia sp.

Pullenia quinqueloba (Reuss)

Alabamina scitula Bandy

Catapsydrax unicavus Bolli, Loeblich and Tappan

Uvigerina cf. rustica Cushman and Edwards

Vaginulinopsis aff. decorata (Reuss)

Planulina sp.

Gaudryina cf. pyramidata Cushman

Nodosaria sp. 3

Cibicidoides laurisae (Mallory)

Cibicidoides sp.

Oolina sp. 
Saracenaria sp.

Uvigerina cf. havanensis Cushman and Bermudez

425

Arenobulimina sp.

430 Bulimina sp.

Catapsydrax dissimilis (Cushman and Bermudez)

Plectofrondicularia vaughanii Cushman

Plectofrondicularia sp.

Stilostomella aculeata (Cushman and Jarvis)

445 Cibicidoides eocaenus (Gumbel)

Globorotalia opima nana Bolli

460 Cassigerinella chipolensis (Cushman and Ponton)

Heterohelix sp. (reworked)

465 Cornuspira involvens Reuss

Globorotalia cf. menardi "A" (caved) Bolli

470

Martinotiella nodulosa (Cushman)

?Upper Eocene

475 Eggerella bradyi (Cushman)

Globigerina cf. euapertura Jenkins

Globigerinatheka cf. index (Finlay)

upper Middle Eocene

480 Acarinina spinuloinflata (Bandy)

Anomalinoides acuta (Plummer)

Globigerinatheka sp.

Nodosaria cf. elegantissima Hantken

Spiroplectammina dentata (Alth)

Turborotalia pomeroli (Toumarkine and Bolli)

485

Bulimina tuxpamensis Cole

Epistomina cf. eocaenica Cushman and Hanna

Haplophragmoides sp.

Trunconotalites rohri Bronnimann and Bermudez

490 Bulimina midwayensis (Cushman and Parker)

Cibicidoides aff. subspiratus (Nuttall)

Cibicidoides truncanus (Gumbel)

Gaudryina laevigata Franke

Turborotalia cerroazulensis cerroazulensis (Cole)

Uvigerina rippensis Cole

495 Arenobulimina sp.

Gavelinella? sp.

$500 \quad$ Heterohelix striata (reworked) (Ehrenberg)

Marginotruncana cf. marginata (reworked) (Reuss)

505 Bulimina alazanensis (Cushman)

Cibicidoides $\mathbf{s p} .18$

Quadrimorphina aff. allomorphinoides (Reuss)

Stilostomella cf. midwayensis (Cushman and Todd)

515 Bulimina trigonalis Ten Dam

530 Subbotina linaperta (Finlay)

535 Uvigerina cf. spinicostata Cushman and Jarvis

555 Globotruncana sp. (reworked)

560 Heterohelix sp. (reworked)

Reophax sp.

lower Middle Eocene
610 Lenticulina sp. (heavy-ribbed species)

Limacina sp. (pteropod)

615 Globigerina soldadoensis Bronniman

620 Govelinella sp.

Limacina canadensis (pteropod) Hodgkinson, Garvie and $\mathrm{Be}$

Loxostoma applinae (Plummer)

630 Citharina sp.

Dorothia trochoides (Marsson)

Globotruncana fornicata (reworked) Plummer

Planorotalites sp.

650* Loxostoma gemmum (d'Orbigny)

655 Lenticulina cf. white Tjalsma and Lohmann

Lower Eocene

685 Pseudohastigerina wilcoxensis (Cushman and Ponton)

705 Quinqueloculina sp.

715 Bulimina bradburyi (Martin)

720 Ammobaculites sp.

Oolina sp.

725 Globigerina eocaena Gumbel

730 Govelinella sp.

755 Karreriella subglabra (Gumbel)

795 Buliminella sp.

805 Bulimina ovata (d'Orbigny)

830 Cibicides west $i$ Howe

Osangularia sp.1

850 Rotaliatina buliminoides (Reuss)

875 Cibicides sp.

910 Ceratocancris sp.1

935 Gyroidina soldanii mamilligera (Andreae)

945 Globigerina sp.

Paleocene

$960 \quad$ Nuttalinella cf. florealis (White)

965 Saccammina sp.

$970 \quad$ Nodosaria cf. minor (Hantken)

Pyramidita rudita (Cushman and Parker)

975 Vulvulina spinosa Cushman

985 Gyroidina octocamerata Cushman and Hanna

Spirillina sp.

990 Gyroidinoides globosus (Hagenow)

Planorotalites chapmani (Parr)

Subbotina frontosa (Subbotina)

$995 \quad$ Neoeponides lunata (Brotzen)

Stilostomella subspinosa (Cushman)

1000 Planorotalites chapmani (Parr) - compressa (Plummer)

Trochammina sp.

Upper Cretaceous

1010

*From this point down, reworked Cretaceous microfossils are more and more frequent, so are not listed. 